\title{
Intracellular Calcium Regulation by Burst Discharge Determines Bidirectional Long-Term Synaptic Plasticity at the Cerebellum Input Stage
}

\author{
David Gall, ${ }^{1,2,4}$ Francesca Prestori, ${ }^{1,2}$ Elisabetta Sola, ${ }^{1,2}$ Anna D'Errico, ${ }^{1}$ Celine Roussel, ${ }^{4}$ Lia Forti, ${ }^{1,2}$ Paola Rossi, ${ }^{1,2}$ and \\ Egidio D'Angelo ${ }^{1,2,3}$ \\ ${ }^{1}$ Department of Cellular-Molecular Physiological and Pharmacological Sciences, University of Pavia, I-27100 Pavia, Italy, ${ }^{2}$ National Institute for the Physics \\ of Matter, I-16152 Genova, Italy, ${ }^{3}$ Department of Functional and Evolutionary Biology, University of Parma, I-34100 Parma, Italy, and ${ }^{4}$ Laboratoire de \\ Neurophysiologie (CP601), Faculte de Medecine, Universite de Bruxelles, B-1070 Bruxelles, Belgium
}

Variations in intracellular calcium concentration $\left(\left[\mathrm{Ca}^{2+}\right]_{\mathrm{i}}\right)$ provide a critical signal for synaptic plasticity. In accordance with Hebb's postulate (Hebb, 1949), an increase in postsynaptic $\left[\mathrm{Ca}^{2+}\right]_{\mathrm{i}}$ can induce bidirectional changes in synaptic strength depending on activation of specific biochemical pathways (Bienenstock et al., 1982; Lisman, 1989; Stanton and Sejnowski, 1989). Despite its strategic location for signal processing, spatiotemporal dynamics of $\left[\mathrm{Ca}^{2+}\right]_{\mathrm{i}}$ changes and their relationship with synaptic plasticity at the cerebellar mossy fiber (mf)- granule cell $(\mathrm{GrC})$ relay were unknown. In this paper, we report the plasticity/[Ca $\left.{ }^{2+}\right]_{\mathrm{i}}$ relationship for GrCs, which are typically activated by mf bursts (Chadderton et al., 2004). Mf bursts caused a remarkable $\left[\mathrm{Ca}^{2+}\right]_{\mathrm{i}}$ increase in $\mathrm{GrC}$ dendritic terminals through the activation of NMDA receptors, metabotropic glutamate receptors (probably acting through $\mathrm{IP}_{3}$-sensitive stores), voltage-dependent calcium channels, and $\mathrm{Ca}^{2+}$-induced $\mathrm{Ca}^{2+}$ release. Although $\left[\mathrm{Ca}^{2+}\right]_{\mathrm{i}}$ increased with the duration of mf bursts, long-term depression was found with a small $\left[\mathrm{Ca}^{2+}\right]_{\mathrm{i}}$ increase (bursts $<250 \mathrm{~ms}$ ), and long-term potentiation (LTP) was found with a large $\left[\mathrm{Ca}{ }^{2+}\right]_{\mathrm{i}}$ increase (bursts $>250 \mathrm{~ms})$. LTP and $\left[\mathrm{Ca}^{2+}\right]_{\mathrm{i}}$ saturated for bursts $>500 \mathrm{~ms}$ and with theta-burst stimulation. Thus, bursting enabled a Ca ${ }^{2+}-\mathrm{dependent}$ bidirectional Bienenstock-Cooper-Munro-like learning mechanism providing the cellular basis for effective learning of burst patterns at the input stage of the cerebellum.

Key words: calcium; LTP; LTD; synaptic plasticity; cerebellum; granule cells

\section{Introduction}

Compelling evidence indicates that variations in intracellular calcium concentration $\left(\left[\mathrm{Ca}^{2+}\right]_{\mathrm{i}}\right)$ regulate the induction of longterm synaptic plasticity (Mulkey and Malenka, 1992; Artola and Singer, 1993), a modification of synaptic strength thought to be the basis for learning and memory in the brain (Bliss and Collingridge, 1993; Malenka and Nicoll, 1999; Bliss et al., 2003). At glutamatergic synapses, $\left[\mathrm{Ca}^{2+}\right]_{i}$ changes depend on the activation of NMDA receptors (NMDA-Rs) and metabotropic glutamate receptors (mGlu-Rs) and can be reinforced by the opening of voltage-dependent $\mathrm{Ca}^{2+}$ channels (VDCCs) and by $\mathrm{Ca}^{2+}$ release from intracellular stores (Jaffe and Brown, 1994; Nishiyama et al., 2000). Hebb's postulate (Hebb, 1949) implies three main

\footnotetext{
Received Jan. 31, 2005; revised April 5, 2005; accepted April 5, 2005.

This work was supported by projects of the European Community (CEREBELLUM QLG3-CT-2001-02256 and SpikeFORCE IST-2001-35271), of the Ministero dell'Instruzione, dell'Università, e della Ricerca, and of the National Institute for the Physics of Matter of Italy (E.D.). This work was also supported by the Belgian Fonds National de la Recherche Scientifique, Fonds Queen Elisabeth Medical Foundation, and Action de Recherche Concertée. C.R. is supported by the Belgian Fonds pour la Recherche dans I'Industrie et l'Agriculture.

Correspondence should be addressed to Egidio D'Angelo, Department of Cellular-Molecular Physiological and Pharmacological Sciences, University of Pavia, Via Forlanini 6, I-27100 Pavia, Italy. E-mail: dangelo@unipv.it.

E. Sola's present address: Department of Neurobiology, International School for Advanced Studies, Via Beirut 4, 1-34014 Trieste, Italy.

D0I:10.1523/JNEUROSCI.0410-05.2005

Copyright $\odot 2005$ Society for Neuroscience $\quad$ 0270-6474/05/254813-10\$15.00/0
}

properties that would allow $\left[\mathrm{Ca}^{2+}\right]_{\mathrm{i}}$ to drive synaptic modifications necessary for neuronal selectivity and network reconfiguration (Bienenstock et al., 1982; Lisman, 1989, 2001, 2003; Stanton and Sejnowski, 1989; Kevin and Sejnowski, 2002): the $\left[\mathrm{Ca}^{2+}\right]_{\mathrm{i}}$ increase (1) needs to be controlled by the specific activity patterns characterizing a particular synaptic relay, (2) should be localized into individual postsynaptic sites to preserve input selectivity, and (3) should cause bidirectional plasticity [comprising longterm depression (LTD) and long-term potentiation (LTP)] to optimize learning capacity. In pyramidal neurons of the hippocampus and neocortex, different activity patterns could indeed induce bidirectional synaptic modifications through a predictable relationship with the $\left[\mathrm{Ca}^{2+}\right]_{\mathrm{i}}$ increase (Neveu and Zucker, 1996; Hansel et al., 1997; Yang et al., 1999; Cho et al., 2001; Cormier et al., 2001) (for review, see Siöström and Nelson, 2002). Moreover, in some studies, it was possible to show that the $\left[\mathrm{Ca}^{2+}\right]_{\mathrm{i}}$ change was limited to dendritic spines or subregions of smooth dendrites (Svoboda et al., 1996; Sabatini et al., 2001, 2002; Augustine et al., 2003; Goldberg et al., 2003). The molecular substrates of the transformation of a monotonic $\left[\mathrm{Ca}^{2+}\right]_{\mathrm{i}}$ increase into bidirectional plasticity, envisioned by Lisman (1989), have also recently received experimental support (DeMaria et al., 2001) (for review, see Lisman, 2001, 2003). In this paper, the existence and properties of bidirectional $\mathrm{Ca}^{2+}$-dependent plas- 
ticity will be investigated at the mossy fiber (mf)-granule cell $(\mathrm{GrC})$ relay, which regulates information transfer at the input stage of the cerebellum.

GrCs receive high-frequency bursts, which could be particularly suitable to process $\left[\mathrm{Ca}^{2+}\right]_{\mathrm{i}}$ signals (Lisman, 1997; Krahe and Gabbiani, 2004), from $\mathrm{mfs}$ after peripheral and central activation (Kase et al., 1980; Szwed et al., 2003; Chadderton et al., 2004). In slice preparations, high-frequency bursts can induce $\mathrm{mf}-\mathrm{GrC}$ LTP through NMDA-R and mGlu-R activation (D'Angelo et al., 1999; Armano et al., 2000; Hansel et al., 2001), but no demonstration of LTD was reported. Moreover, although previous observations suggested the involvement of $\mathrm{Ca}^{2+}$-dependent mechanisms, these have never been investigated. Reports in cell culture have revealed $\mathrm{Ca}^{2+}$ entering through NMDA and VDCCs and released by inositol 1,4,5-trisphosphate $\left(\mathrm{IP}_{3}\right)$ and ryanodinsensitive intracellular $\mathrm{Ca}^{2+}$ stores (Irving et al., 1992a,b; Simpson et al., 1996; del Rio et al., 1999; Masgrau et al., 2001; Monti et al., 2002); however, because $\left[\mathrm{Ca}^{2+}\right]_{\mathrm{i}}$ changes were stimulated by exogenous drug application and measured in the soma, neither their input specificity nor their relationship with input patterns or synaptic plasticity could be assessed.

In this paper, we investigated $\left[\mathrm{Ca}^{2+}\right]_{\mathrm{i}}$ dynamics during repetitive neurotransmission at the cerebellar $\mathrm{mf}-\mathrm{GrC}$ synapse by combining $\mathrm{Ca}^{2+}$ imaging with the patch-clamp technique in acute cerebellar slices. NMDA-R- and mGlu-R-dependent $\left[\mathrm{Ca}^{2+}\right]_{\mathrm{i}}$ increase occurred prominently in $\mathrm{GrC}$ dendritic endings and was locally amplified by VDCCs and intracellular $\mathrm{Ca}^{2+}$ stores. Interestingly, the $\left[\mathrm{Ca}^{2+}\right]_{\mathrm{i}}$ increase reflected the duration of mf bursts, revealing a Bienenstock-Cooper-Munro (BCM)like relationship (Bienenstock et al., 1982) in which LTD appeared for short isolated bursts causing small $\left[\mathrm{Ca}^{2+}\right]_{\mathrm{i}}$ changes and LTP appeared for long or repeated bursts causing relatively large $\left[\mathrm{Ca}^{2+}\right]_{\mathrm{i}}$ changes. The efficient translation of $\mathrm{mf}$ input bursts into local $\left[\mathrm{Ca}^{2+}\right]_{\mathrm{i}}$ changes and bidirectional long-term synaptic plasticity may have relevant consequences for network computation underlying cerebellar sensorimotor control.

\section{Materials and Methods}

Slice preparation and electrophysiology. Parasagittal cerebellar slices (200 $\mu \mathrm{m}$ thick) were cut from the vermis of 19- to 23-d-old Wistar rats. Rats were decapitated after deep anesthesia with halothane (Sigma, St. Louis, $\mathrm{MO})$. Slices were incubated for at least $1 \mathrm{~h}$ at $32^{\circ} \mathrm{C}$ in oxygenated extracellular solution containing the following (in mM): $120 \mathrm{NaCl}, 2 \mathrm{KCl}, 2$ $\mathrm{CaCl}_{2}, 1.19 \mathrm{MgSO}_{4}, 1.18 \mathrm{NaH}_{2} \mathrm{PO}_{4}, 26 \mathrm{NaHCO}_{3}$, and 10 glucose, $\mathrm{pH} 7.4$, when equilibrated with $95 \% \mathrm{O}_{2}-5 \% \mathrm{CO}_{2}$. Slices were later transferred to the recording chamber and perfused $(1-1.5 \mathrm{ml} / \mathrm{min})$ with the same extracellular solution, except for some voltage-clamp recordings in which $\mathrm{Mg}^{2+}$ was omitted. Unless otherwise stated, the solution contained a 10 $\mu \mathrm{M}$ concentration of the $\mathrm{GABA}_{\mathrm{A}}$ receptor blocker bicuculline (Sigma). Drugs were perfused in the bath. 2-amino-5-phosphonovaleric acid (APV), 7-chlorokinurenic acid, (RS)-1-amino-indan-1,5-dicarboxylic acid (AIDA), and thapsigargin were purchased from Tocris Cookson (Bristol, UK). Oregon Green 488 BAPTA-1 (OG1) was purchased from Molecular Probes (Eugene, OR). All recordings were made with an Axopatch 200A amplifier (Molecular Devices, Union City, CA) at room temperature $\left(20-23^{\circ} \mathrm{C}\right)$. Membrane current and potential were recorded using the voltage-clamp mode and the fast current-clamp mode of the amplifier, respectively (D'Angelo et al., 1995, 1997, 1998, 2001). All recordings were made at a cutoff frequency of $10 \mathrm{kHz}$ and subsequently digitized at $20 \mathrm{kHz}$ using the acquisition software pClamp (Molecular Devices) in combination with a Digidata $1200 \mathrm{~B}$ analog-to-digital converter (Molecular Devices). Patch pipettes were pulled from borosilicate glass capillaries (Hilgenberg, Malsfeld, Germany) and had a resistance of 5-8 $\mathrm{M} \Omega$ when filled with the intracellular solution. For experiments combining voltage-clamp and fluorescence $\mathrm{Ca}^{2+}$ imaging, whole-cell
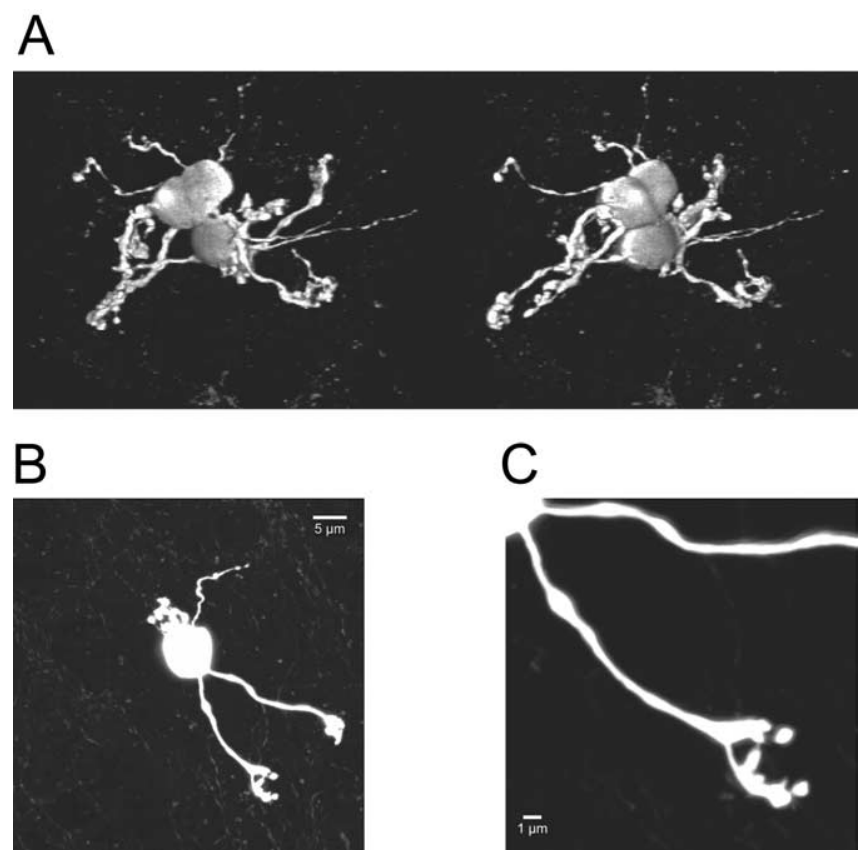

Figure 1. GrC morphology. $\boldsymbol{A}$, Stereoscopic view obtained by three-dimensional reconstruction of confocal images of three adjacent biocytin-filled GrCs at postnatal day 21, illustrating the high cellular density of the cerebellar granular layer. $\boldsymbol{B}, Z$-projection of confocal images of a single $\operatorname{GrC}$ at postnatal day 23. Scale bar, $5 \mu \mathrm{m}$. C, Detailed view of a dendritic terminal of the $\mathrm{GrC}$ shown in $\boldsymbol{B}$, showing a typical claw-like structure. Scale bar, $1 \mu \mathrm{m}$.

recording pipettes were filled with the following (in $\mathrm{mm}$ ): $140 \mathrm{CsCl}, 4.6$ $\mathrm{MgCl}_{2}, 10$ HEPES, $4 \mathrm{Na}$-ATP, $0.4 \mathrm{Na}-\mathrm{GTP}$, and $0.2 \mathrm{OG} 1$, pH adjusted at 7.3 with $\mathrm{CsOH}$. In whole-cell recordings used for morphological reconstruction, the same pipette-filling solution contained $0.4 \%$ biocytin instead of OG1. For experiments combining current-clamp and fluorescence $\mathrm{Ca}^{2+}$ imaging, the pipette solution was the following (in $\mathrm{mM}$ ): 126 K-gluconate, $4.6 \mathrm{MgCl}_{2}$, 5 HEPES, $4 \mathrm{Na}$-ATP, $0.4 \mathrm{Na}$-GTP, 15 glucose, and $0.2 \mathrm{OG} 1, \mathrm{pH}$ adjusted at 7.3 with $\mathrm{KOH}$. In experiments on synaptic plasticity, we used this same intracellular solution, except that OG1 was substituted with a buffer composed of $0.1 \mathrm{~mm} \mathrm{BAPTA}$ and $0.02 \mathrm{mM} \mathrm{CaCl}_{2}$ (D'Angelo et al., 1995, 1997, 1998). The mf bundle was stimulated with a bipolar tungsten electrode via a stimulus isolation unit using $200 \mu \mathrm{s}, 10 \mathrm{~V}$ pulses, which activate between 2 and $4(2.9 \pm 1.1 ; n=8)$ synapses per $\mathrm{GrC}$ in comparable experimental conditions (Sola et al., 2004) (E. D'Angelo and E. Sola, unpublished observations). High-frequency pulses were delivered either as theta-burst stimulation (TBS) (four $100 \mathrm{~ms}, 100$ $\mathrm{Hz}$ bursts of impulses repeated every $250 \mathrm{~ms}$ ) or continuous stimulation (one burst of duration ranging from 100 to $1000 \mathrm{~ms}$ at $100 \mathrm{~Hz}$ ).

The stability of patch-clamp recordings can be influenced by modifications of series resistance and neurotransmitter release. To ensure that series resistance remained stable during the recordings, passive cellular parameters were extracted in voltage clamp by analyzing current relaxation induced by a $10 \mathrm{mV}$ step from a holding potential of $-70 \mathrm{mV}$. The GrC has a compact structure and behaves like a single electrotonic compartment (Silver et al., 1992; D’Angelo et al., 1993, 1995). Accordingly, the transients were reliably fitted with a monoexponential function yielding membrane capacitance $\left(C_{\mathrm{m}}\right)$ of $2.8 \pm 0.1 \mathrm{pF}(n=40)$, membrane resistance $\left(R_{\mathrm{m}}\right)$ of $1.7 \pm 0.2 \mathrm{G} \Omega(n=40)$, and series resistance $\left(R_{\mathrm{s}}\right)$ of $26.7 \pm 3.2 \mathrm{M} \Omega(n=40)$. The $-3 \mathrm{~dB}$ cell plus electrode cutoff frequency was $f_{\mathrm{VC}}=\left(2 \pi R_{\mathrm{s}} C_{\mathrm{m}}\right)^{-1}=2.1 \pm 0.2 \mathrm{kHz}(n=42)$ and did not significantly change during imaging or synaptic plasticity recordings ( $6 \pm 1 \%$; $p=0.78)$ attesting their stability.

Data are reported as mean \pm SEM, and, unless otherwise indicated, statistical comparisons are done using paired Student's $t$ test.

Calcium imaging. GrCs were identified using an upright Axioskop 2 microscope (Zeiss, Oberkochen, Germany) with a $63 \times, 0.9$ numerical aperture water-immersion objective (Olympus, Hamburg, Germany). 
A

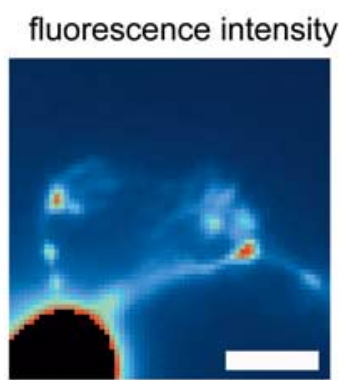

B

\section{C}
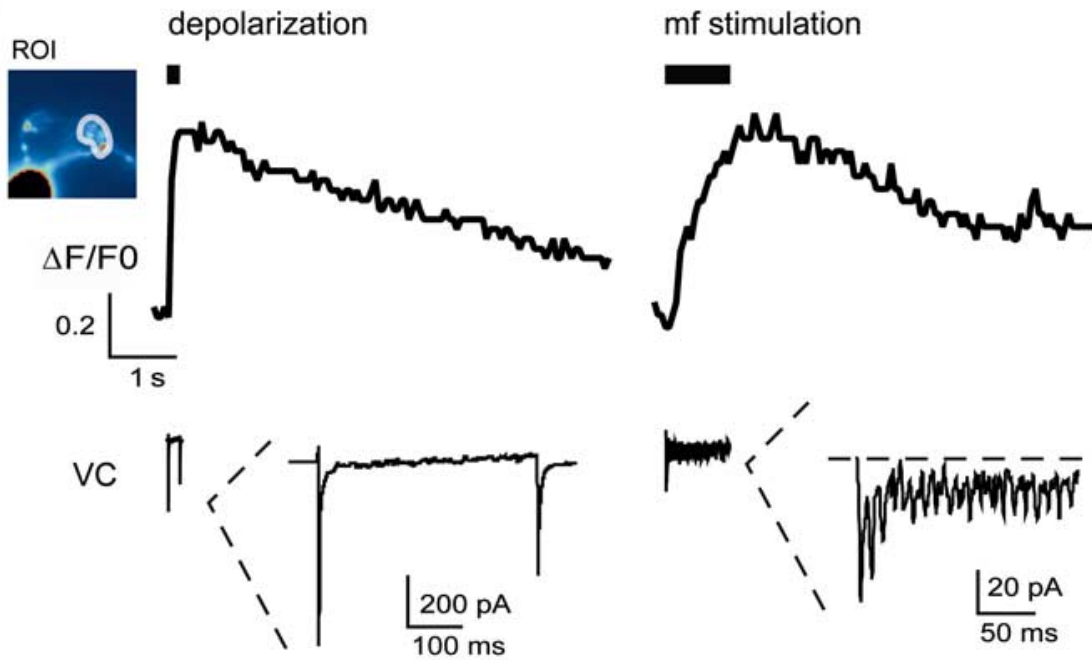

Figure 2. $\quad \mathrm{Ca}^{2+}$ transients elicited by either membrane depolarization or high-frequency mf stimulation. $\boldsymbol{A}$, Unprocessed fluorescence image of a GrC filled with $200 \mu \mathrm{m}$ 0G1. Scale bar, $5 \mu \mathrm{m}$. Fluorescence intensity is color coded with arbitrary units within an interval chosen to allow the visualization of the synaptic terminals (note that, although the soma fluorescence appears saturated within this interval, it does not saturate the CCD detectors). The shape of a glomerulus is clearly visible at the terminal portion of the dendrite. $\boldsymbol{B}$, During voltage-clamp recordings, we measured the $\mathrm{Ca}^{2+}$ transients induced either by a $200 \mathrm{~ms}$ depolarization from -70 to $0 \mathrm{mV}$ or by high-frequency $\mathrm{mf}$ stimulation ( $1 \mathrm{~s}$ at $100 \mathrm{~Hz}$ ) while holding the $\mathrm{GrC}$ at $-70 \mathrm{mV}$ in the absence of extracellular $\mathrm{Mg}^{2+}$. The corresponding time series of pseudoratio images from this GrC (warmer color code for higher $\left.\Delta F / F_{0}\right)$ is shown. The $\mathrm{Ca}^{2+}$ increase is maximal at the level of the glomerulus during both depolarization and mf stimulation. $C$, $\Delta F / F_{0}$ is evaluated in the ROl (inset) at the level of the glomerulus for the same cell as in $\boldsymbol{A}$ and $\boldsymbol{B}$. Depolarization and $\mathrm{mf}$ stimulation induce $\mathrm{Ca}^{2+}$ transients of similar maximal amplitude at the synaptic level. In this and subsequent figures, depolarization and $\mathrm{mf}$ stimulation are indicated by black bars. The voltage-clamp (VC) current elicited by depolarization and mf stimulation is shown at the bottom on the same time scale as the $\mathrm{Ca}^{2+}$ transient and is expanded in the inset. During depolarization, a large peak $\mathrm{Na}^{+}$current is followed by a persistent component partially masked by outward $\mathrm{K}^{+}$currents (the $\mathrm{Ca}^{2+}$ current is clearly visible only under selective ionic conditions) (Rossi et al., 1994). During mf stimulation, the EPSC oscillations are associated with a steady current mostly determined by NMDA channels (Rossi et al., 2002).

Digital fluorescence images were obtained using an excitation light source from T.I.L.L. Photonics (Planegg, Germany) combined with a Molecular Devices acquisition system. Briefly, to excite fluorescence of the $\mathrm{Ca}^{2+}$ dye OG1 (Forti et al., 2000; Sabatini et al., 2001, 2002), light from a $75 \mathrm{~W}$ xenon lamp was focused on a scanning monochromator set at $488 \mathrm{~nm}$ and coupled, by an optical fiber and a lens, to the microscope equipped with a dichroic mirror and a high-pass emission filter centered at 505 and $507 \mathrm{~nm}$, respectively. Images were acquired by a Peltier-cooled PCO Imaging (Kelheim, Germany) SensiCam CCD camera with a resolution of $640 \times 480$ pixels and a $2 \times 2$ binning (giving a $0.2 \mu \mathrm{m}$ pixel size after $63 \times$ magnification). During recordings, images were acquired with a $40 \mathrm{~ms}$ exposure/image at video rate. Acquisition started after allowing $>2 \mathrm{~min}$ for dye loading in the neuron. After this time, the resting fluorescence $\left(F_{0}\right)$ varied by $<5 \%$ in each analyzed cell region for the entire recording time, indicating that OG1 concentration was stable. The background fluorescence $\left(B_{0}\right)$ was also stationary. For example, for the group of imaging experiments shown in Figure 2, showing calcium transients in the synaptic terminals elicited by either membrane depolarization or high-frequency mossy fiber stimulation, the variation of $B_{0}$ and $F_{0}$ between the two successive experimental protocols was $F_{0}=139.06 \pm 25.02$ and $B_{0}=95.56 \pm$ 8.50 for depolarization experiments and $F_{0}=$ $138 \pm 21.54$ and $B_{0}=97.86 \pm 11.30$ for the mossy fiber stimulation experiments $(n=7$; differences were statisticallly not significant). A fast OG1 perfusion was favored by the small size of the somatodendritic compartment of GrCs [it should be noted that internal perfusion of the $\mathrm{Na}^{+}$channel blocker 2(triethylamino)-N(2,6-dimethylphenyl) acetamine takes a comparable time to block $\mathrm{GrC}$ spikes] (D'Angelo et al., 1993, 1999; Rossi et al., 1994). All stimulation protocols were separated by a minimum of $60 \mathrm{~s}$ to allow $\left[\mathrm{Ca}^{2+}\right]_{\mathrm{i}}$ to return to basal level. Cell damage was identified by the following signs: the failure of $200 \mathrm{~ms}$ depolarization at 0 $\mathrm{mV}$ in voltage clamp to elicit a fluorescence transient or the sudden inability of fluorescence levels to recover to baseline after stimulation. Such experiments were not analyzed. We never observed bleaching of OG1 basal fluorescence during individual stimulations.

Stimulus-induced fluorescence changes were analyzed off-line in the regions of interest (ROIs). For each experiment, regions were drawn by eye defining the ROIs in the first image of a sequence, thus giving a set of twodimensional arrays of pixels. In addition, background fluorescence was evaluated by defining a background area of a similar size close to the cell. For each ROI, a measurement of the relative change in fluorescence during cell stimulation, $\Delta F / F_{0}$, was obtained as follows. (1) For each consecutive $n$th image in the sequence, the fluorescence intensity, $f(n)$, was evaluated in the ROI. (2) Background fluorescence was measured simultaneously in the background area, $B(n)$. Care was taken to check that background fluorescence was stationary. (3) The background-subtracted fluorescence, $F(n)=$ $f(n)-B(n)$, was then used to evaluate $\Delta F /$ $F_{0}(n)=\left(F(n)-F_{0}\right) / F_{0}$, where $F_{0}$ is the average background-subtracted resting fluorescence over three consecutive images before applying the stimulus. This background-subtraction procedure was used to account for slice autofluorescence and/or fluorescence arising from outflow of dye from the pipette before seal formation. ROIs for analysis of somatic signals were chosen near the visible soma border to minimize the unfavorable surface/volume ratio for estimation of near-membrane $\mathrm{Ca}^{2+}$ changes. Analysis of images was performed with Axon Imaging Workbench software (Molecular Devices).

It should be noted that intracellular buffers, such as BAPTA and OG1, have to be carefully calibrated to maintain efficient $\mathrm{Ca}^{2+}$ homeostasis and neuronal functional properties (D'Angelo et al., 1995; Forti et al., 2000). The BAPTA buffer, which was extensively tested in the last years in our laboratory, allows induction of $\mathrm{mf}-\mathrm{GrCl}$ long-term synaptic plasticity (see Fig. 9B) (D'Angelo et al., 1999; Rossi et al., 2002) with properties indistinguishable from those observed using perforated-patch or field recordings (Armano et al., 2000; Maffei et al., 2002). Moreover, GrC intrinsic excitability measured with BAPTA or in perforated-patch recordings is indistinguishable (Gall et al., 2003). OG1 has a $\mathrm{Ca}^{2+}$ affinity very similar to BAPTA allowing, therefore, a direct comparison of imaging with patch-clamp recordings. Indeed, the firing pattern observed 
using OG1 (see Fig. 7) was indistinguishable from that observed using BAPTA (D'Angelo et al., 1995, 1997, 1998). $\left[\mathrm{Ca}^{2+}\right]_{\mathrm{i}}$ changes in imaging recordings did not saturate OG1, as indicated by the significant increase in $\Delta F / F_{0} \mathrm{ob}$ served with double TBS protocols (see Fig. 6) and by control recordings performed with the low-affinity dye Mg fura-2 (data not shown). Moreover, although OG1 tends to slow down $\left[\mathrm{Ca}^{2+}\right]_{\mathrm{i}}$ kinetics (Sabatini et al., 2001, 2002), these could be significantly accelerated by blocking release from intracellular stores (see Fig. 5), indicating that OG1 was not rate limiting.

Morphological reconstruction. In some experiments, recorded GrCs were filled with $0.4 \%$ biocytin and identified by immunocytochemistry. To this end, slices were fixed by immersion in $4 \%$ paraformaldehyde overnight. Biocytin was revealed with streptavidin-conjugated fluorescein isothiocyanate (FITC) (Biosys, Compiègne, France) diluted 1:200 or with cyanine 3 diluted 1:200. After three rinses in TBS, slices were mounted on coverslips with SlowFade Light anti-fade mounting medium (Molecular Probes) in 50\% glycerol and secured with nail polish. GrCs were viewed on an LSM 510 META NLO laser-scanning confocal microscope (Zeiss) equipped with a C-Apochromat $63 \times / 1.2$ objective (Zeiss). The excitation beam of an He/Ne laser ( $488 \mathrm{~nm}$ ) and bandpass emission filters $(522 / 35 \mathrm{~nm})$ were used for selective detection of the green or red fluorochrome. Sequential optical sections were taken at $0.5 \mu \mathrm{m}$ intervals in the $z$-axis to build an image volume in three dimensions on a personal computer equipped with a single Intel XEON $2.40 \mathrm{GHz}$ processor (Fujitsu Siemens, Bad Homburg, Germany) using Zeiss LSM 510 software.

\section{Results}

General properties of GrC physiology and morphology

In this study, we investigated intracellular $\mathrm{Ca}^{2+}$ dynamics and their relationship with long-term synaptic plasticity at the mfGrC synapse in acute slices from 19- to 23-d-old rat cerebellum. At this age, GrCs have almost concluded their development from a $\mathrm{Ca}^{2+}$ - to $\mathrm{Na}^{+}$-dependent firing mode (D'Angelo et al., 1997). Here, we considered only recordings from GrCs displaying a peak $\mathrm{Na}^{+}$current of $>300 \mathrm{pA}$ during a $40 \mathrm{~ms}$ depolarizing step from -70 to $0 \mathrm{mV}$ (see Fig. $2 \mathrm{C}$, inset), which is typical of fast $\mathrm{Na}^{+}$spiking GrCs (D’Angelo et al., 1994) (J. Magistretti, L. Castelli, and D'Angelo, unpublished observations). In current clamp, all recorded $\mathrm{GrCs}$ indeed showed fast repetitive spike discharge (see Fig. 7). $C_{\mathrm{m}}(2.8 \pm 0.12 \mathrm{pF} ; n=40)$ and $R_{\mathrm{m}}(1.74 \pm 0.17 \mathrm{G} \Omega ; n=$ 40) were in agreement with values reported for mature GrCs (D’Angelo et al., 1997; Cathala et al., 2003). Finally, because GrC development is characterized by a decrease in soma size and dendrite number, we only considered GrCs displaying mature morphological features (Figs. 1, 2).

The fine morphology of GrCs was reconstructed with confocal imaging (Fig. 1) in a representative sample of recordings, in which the pipette-filling solution contained $0.4 \%$ biocytin. GrCs had a soma diameter of $7.8 \pm 0.2 \mu \mathrm{m}$ and $4.0 \pm 0.5(n=7)$ dendrites, in agreement with values reported for mature GrCs (Cathala et al., 2003). The dendrites extended for $<25 \mu \mathrm{m}$ (lower limit for planar projection) and terminated with claw-like structures (dendritic digits), which are characteristic of mature mfGrC synapses and take part to constitute the cerebellar glomerulus (Jakab and Hamori, 1988). This morphology was also revealed during optical imaging with OG-1, although with lower resolution, allowing a precise localization of the dendritic substructures used for measuring $\left[\mathrm{Ca}^{2+}\right]_{\mathrm{i}}$ changes (Fig. 2A).

Several mechanisms have been identified that could contribute to raise $\left[\mathrm{Ca}^{2+}\right]_{\mathrm{i}}$ in GrCs taking part in the induction of longterm synaptic plasticity. These include NMDA and mGlu receptors, intracellular $\mathrm{Ca}^{2+}$ stores, and VDCCs (D'Angelo et al., 1999; Armano et al., 2000; Maffei et al., 2002; Rossi et al., 2002), as considered below.

\section{$\left[\mathrm{Ca}^{2+}\right]_{\mathrm{i}}$ transients elicited by membrane depolarization and mf stimulation}

To measure $\left[\mathrm{Ca}^{2+}\right]_{\mathrm{i}}$ changes, GrCs were loaded with an intracellular solution containing $200 \mu \mathrm{M}$ OG1 using the whole-cell configuration of the patch-clamp technique. $\left[\mathrm{Ca}^{2+}\right]_{i}$ changes were first elicited during voltage-clamp recordings by depolarizing GrCs from -70 to $0 \mathrm{mV}$ for $200 \mathrm{~ms}$. In this case, $\mathrm{Ca}^{2+}$ enters through VDCCs, which, in GrCs, open at high threshold (more than $-40 \mathrm{mV}$ ) (Rossi et al., 1994). $\left[\mathrm{Ca}^{2+}\right]_{\mathrm{i}}$ increased in the dendrites, more evidently in the terminal digits. $\left[\mathrm{Ca}^{2+}\right]_{\mathrm{i}}$ transients 

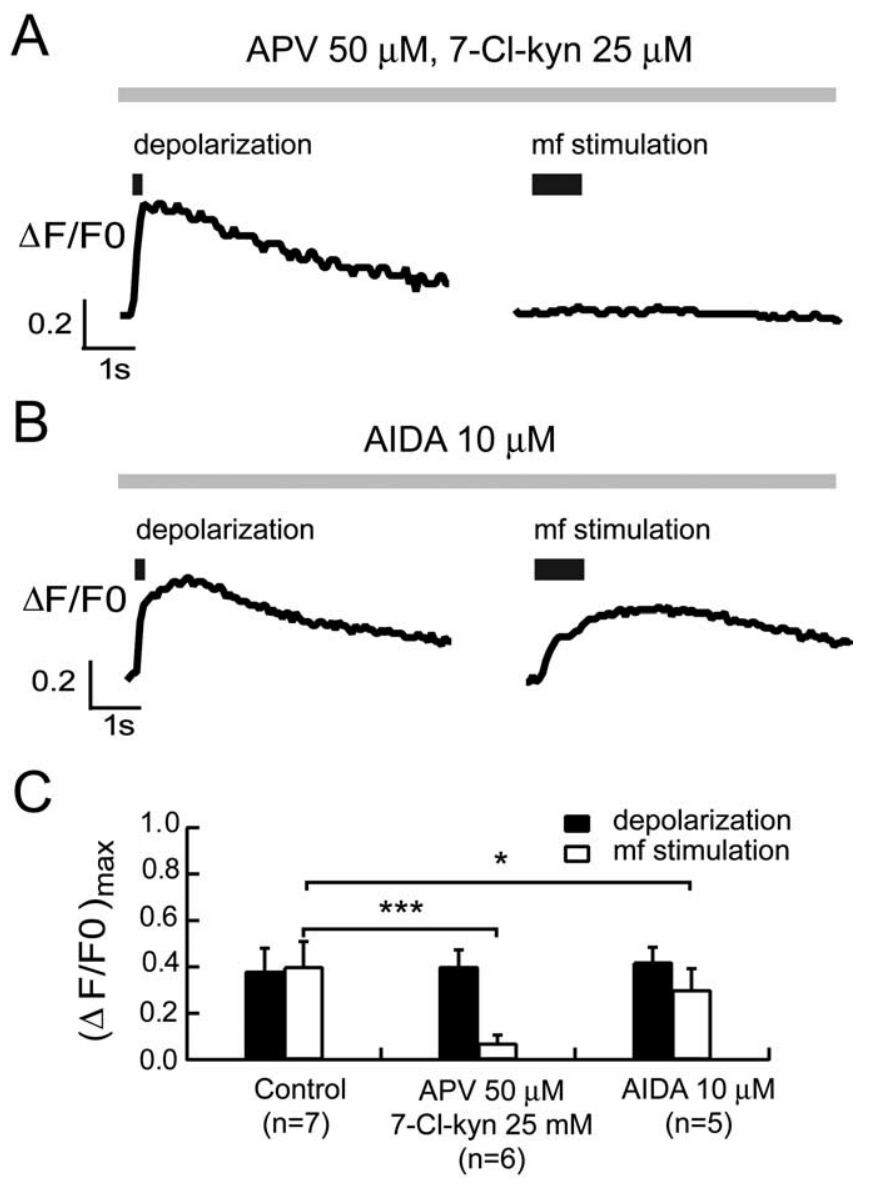

Figure 4. Effect of NMDA-R and mGlu-R1 blockers on $\left[\mathrm{Ca}^{2+}\right]_{i}$ transients. We investigated the effect of NMDA-R and mGlu-R1 antagonists on the synaptic $\left[\mathrm{Ca}^{2+}\right]_{\mathrm{i}}$ transients induced by either a $200 \mathrm{~ms}$ depolarization from -70 to $0 \mathrm{mV}$ or high-frequency mf stimulation ( $1 \mathrm{~s}$ at 100 $\mathrm{Hz}$ ) while holding $\mathrm{GrCs}$ at $-70 \mathrm{mV}$ in the absence of extracellular $\mathrm{Mg}^{2+}$. $\boldsymbol{A}$, In the presence of NMDA-R blockers, mf stimulation was unable to induce any $\left[\mathrm{Ca}^{2+}\right]_{i}$ increase, whereas the amplitude of depolarization-induced $\left[\mathrm{Ca}^{2+}\right]_{\mathrm{i}}$ transients was unaltered on the same $\mathrm{GrC} . \boldsymbol{B}$, Inhibition of mGlu-R1 decreased the maximal amplitude of the $\left[\mathrm{Ca}^{2+}\right]_{\mathrm{i}}$ response determined by synaptic stimulation compared with that induced by depolarization on the same cell. $\mathbf{C}$, Histograms report the $\left(\Delta F / F_{0}\right)_{\max }$ induced by either depolarization or high-frequency mf stimulation in control conditions and in the presence of NMDA-Rantagonists ( $50 \mu \mathrm{m}$ APV plus $25 \mu \mathrm{M}$ 7-(I-kyn,) or mGlu-R1 antagonist (AIDA, $10 \mu \mathrm{M})$. Data are reported as mean \pm SEM, and statistical differences are indicated: ${ }^{*} p<0.05$; ${ }^{* * *} p<0.001$. In this and subsequent figures, $\mathrm{Ca}^{2+}$ signals are measured in the dendritic endings. Error bars represent SEM.

showed a maximum $\Delta F / F_{0}$ amplitude $\left[\left(\Delta F / F_{0}\right)_{\max }\right]$ of $0.38 \pm$ $0.035(n=18)$ in the dendritic endings. The $\left[\mathrm{Ca}^{2+}\right]_{\mathrm{i}}$ change peaked at the end of the $200 \mathrm{~ms}$ stimulus pulse and decayed monotonically with a half width (HW) (duration at half of peak amplitude) of $2.3 \pm 0.22 \mathrm{~s}(n=18)$. In the soma, $\left(\Delta F / F_{0}\right)_{\max }$ averaged $0.06 \pm 0.017(p<0.001 ; n=18)$ and was virtually undetectable in at least $75 \%$ of cases (data not shown). It should be noted that maximal $\left[\mathrm{Ca}^{2+}\right]_{\mathrm{i}}$ transients generated by membrane depolarization in voltage clamp showed little variability throughout the different recordings reported in the present paper and have been taken as an internal control for the reliability of recording conditions and $\mathrm{GrC} \mathrm{Ca}^{2+}$ regulation.

$\left[\mathrm{Ca}^{2+}\right]_{\mathrm{i}}$ changes caused by $\mathrm{mf}$ synaptic transmission were investigated by delivering $100 \mathrm{~Hz}, 1 \mathrm{~s}$ trains of stimuli. GrCs were maintained under voltage clamp at $-70 \mathrm{mV}$ in $\mathrm{Mg}^{2+}$-free solution, so that NMDA channels were unblocked and could open without activating VDCCs (D'Angelo et al., 1995; Rossi et al., 2002). The $\left[\mathrm{Ca}^{2+}\right]_{\mathrm{i}}$ increase induced by $\mathrm{mf}$ stimulation was high
A

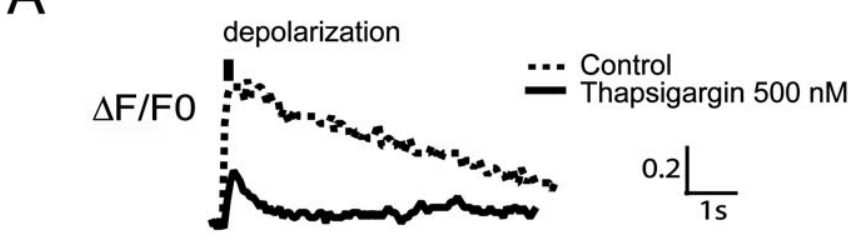

B

- Control

ㅁ Thapsigargin $500 \mathrm{nM}$
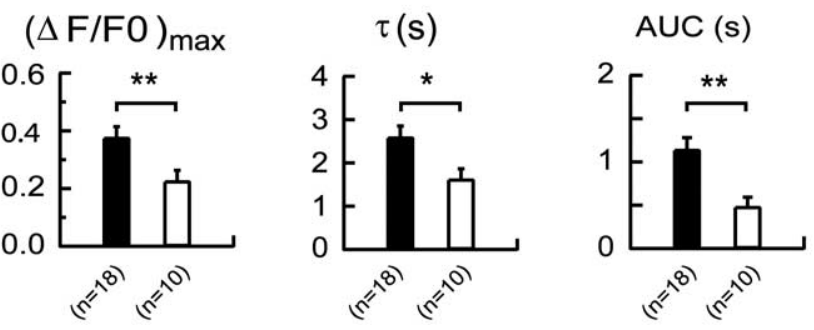

Figure 5. Effect of thapsigargin on $\left[\mathrm{Ca}^{2+}\right]_{\mathrm{i}}$ transients. $\left[\mathrm{Ca}^{2+}\right]_{\mathrm{i}}$ transients were induced by a 200 ms depolarization from -70 to $0 \mathrm{mV}$ after 30 min of slice preincubation with $500 \mathrm{~nm}$ thapsigargin. $\boldsymbol{A}$, The depolarization-induced $\left[\mathrm{Ca}^{2+}\right]_{i}$ transient (continuous line) shows a reduced maximal amplitude $\left(\Delta F / F_{0}\right)_{\max }$ and a faster decay $(\tau)$, giving a reduced AUC compared with signals generated in control conditions. To facilitate comparison, the time course of a typical $\left[\mathrm{Ca}^{2+}\right]_{\mathrm{i}}$ transient recorded without thapsigargin pretreatment in a different $\mathrm{GrC}$ (Fig. 2) is shown as a dotted line. $B$, The histogram compares the $\left(\Delta F / F_{0}\right)_{\max } \tau$, and AUC of $\left[\mathrm{Ca}^{2+}\right]_{\mathrm{i}}$ transients induced by depolarization in control experiments and after thapsigargin pretreatment. Data are reported as mean \pm SEM, and statistical differences are indicated: ${ }^{*} p<0.05$; ${ }^{* *} p<0.01$. Error bars represent SEM.

in the dendritic endings $\left[\left(\Delta F / F_{0}\right)_{\max }=0.40 \pm 0.11\right]$ (Fig. $\left.2 B, C\right)$ but was barely visible at the somatic level $\left[\left(\Delta F / F_{0}\right)_{\max }=0.05 \pm 0.02 ; p<\right.$ $0.05 ; n=7]$. In the same GrCs, at the dendritic endings, depolarization gave $\left[\mathrm{Ca}^{2+}\right]_{\mathrm{i}}$ transients with $\left(\Delta F / F_{0}\right)_{\max }$ of $0.38 \pm 0.10(n=7)$ (Fig. $2 B, C$ ).

\section{Localization of $\mathrm{Ca}^{2+}$ signals}

A striking aspect of present recordings is the much stronger intensity of $\mathrm{Ca}^{2+}$ signals in the dendrites than in the soma. On closer inspection, both synaptically and depolarization-evoked $\mathrm{Ca}^{2+}$ transients showed a significant $(p<0.01 ; n=7)$ progressive decay from the dendritic ending toward the soma (Fig. $3 A, B)$. In the same data set, we compared $\left[\mathrm{Ca}^{2+}\right]_{\mathrm{i}}$ transients in all dendrites (two to four) visible in the focal plane. Although membrane depolarization elicited well detectable $\left[\mathrm{Ca}^{2+}\right]_{\mathrm{i}}$ signals in all dendrites $\left[\left(\Delta F / F_{0}\right)_{\max }>0.05\right]$, this was the case only for $75 \%(15$ of 20) of dendrites during $\mathrm{mf}$ stimulation. In the remaining $25 \%$ dendrites, there was no detectable fluorescence at all $\left[\left(\Delta F / F_{0}\right)_{\max }<\right.$ 0.01 ], reflecting failure to activate all of the synapses impinging on a given $\mathrm{GrC}$. The efficiency of $\mathrm{mf}$ stimulation (75\%) is similar to that revealed in comparable experimental conditions by using quantal analysis (72.5\%) (Sola et al., 2004) (D'Angelo and Sola, unpublished results). These results indicated that the effect of synaptic activation on $\left[\mathrm{Ca}^{2+}\right]_{\mathrm{i}}$ changes in voltage clamp was confined to individual dendrites.

It should also be noted that previous electrotonic analysis revealed that membrane potential decay from the soma to dendritic endings of GrCs during voltage clamp is $\sim 1 \%$ when either synaptic channels (D’Angelo et al., 1995) or VDCCs (Rossi et al., 1994) open in the dendritic endings. This is attributable to the 
A
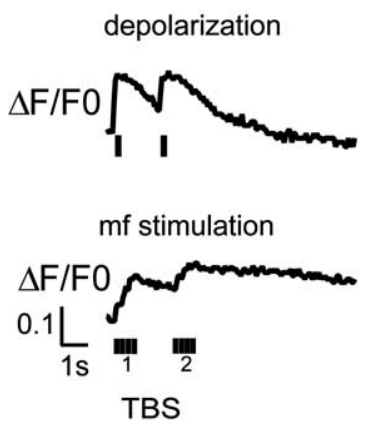

B

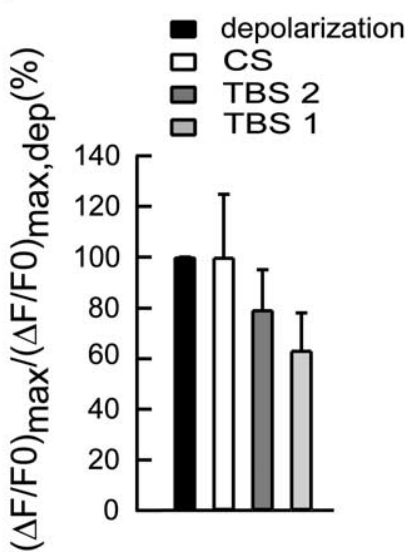

Figure 6. $\left[\mathrm{Ca}^{2+}\right]_{\mathrm{i}}$ increase induced by TBS. $A, \mathrm{TBS}$ was composed of four $100 \mathrm{~Hz}$ bursts every $250 \mathrm{~ms}$, during which membrane potential was stepped from -70 to $-40 \mathrm{mV}$ in voltage clamp (1.2 mm external $\mathrm{Mg}^{2+}$ ) (D'Angelo et al., 1999; Rossi et al., 2002). TBS caused a marked $\left(\Delta F / F_{0}\right)_{\max }$ increase (bottom trace). Application of a second TBS after $2 \mathrm{~s}$ determined an additional $\left(\Delta F / F_{0}\right)_{\max }$ increase. The $\left(\Delta F / F_{0}\right)_{\max }$ induced by TBS is compared with that caused by 200 ms depolarization from -70 to $0 \mathrm{mV}$ (top trace) in the same cell. $\boldsymbol{B}$, The $\left(\Delta F / F_{0}\right)_{\text {max }}$ determined by continuous $1000 \mathrm{~ms} \mathrm{mf}$ stimulation (as in Fig. 2), TBS 1, and TBS 2 (as in $A$ ) are compared. $\left(\triangle F / F_{0}\right)_{\max }$ is normalized by the value measured during a voltage-clamp depolarization, $(\Delta F /$ $\left.F_{0}\right)_{\text {max,dep, }}$, providing a partial compensation for nonlinear actions of $\mathrm{Mg}^{2+}$ on neurotransmitter release and VDCC permeability. Data are reported as mean \pm SEM. Error bars represent SEM.

fact that GrCs are electrically compact, with an electrotonic length of just 0.04 (Silver et al., 1992; D'Angelo et al., 1993). In addition, present recordings were performed in the absence of extracellular $\mathrm{Mg}^{2+}$; therefore, voltage sensitivity of NMDA channels was abolished. Thus, it is extremely unlikely that $\mathrm{Ca}^{2+}$ transient decay along the dendrite reflects a membrane potential gradient. These observations support a regional localization of $\mathrm{Ca}^{2+}$ signaling as reported in other central neurons in situ (Svoboda et al., 1996; Sabatini et al., 2001, 2002; Augustine et al., 2003; Goldberg et al., 2003).

\section{The role of NMDA-Rs and mGlu-Rs in $\left[\mathrm{Ca}^{2+}\right]_{\mathrm{i}}$ changes}

The relative contribution of NMDA-Rs and mGlu-Rs in the initiation of synaptic $\mathrm{Ca}^{2+}$ signals during repetitive $\mathrm{mf}$ stimulation (D’Angelo et al., 1999; Armano et al., 2000; Maffei et al., 2002) was evaluated using the same recording approach shown in Figure 2. We investigated the effect of NMDA-R ( $50 \mu \mathrm{M}$ APV plus 25 $\mu \mathrm{M}$ 7-Cl-kyn) and mGlu-R1 (10 $\mu \mathrm{M}$ AIDA) antagonists on synaptic $\left[\mathrm{Ca}^{2+}\right]_{\mathrm{i}}$ transients induced by either high-frequency $\mathrm{mf}$ stimulation $(1 \mathrm{~s}$ at $100 \mathrm{~Hz})$ at $-70 \mathrm{mV}$ or a $200 \mathrm{~ms}$ depolarization from -70 to $0 \mathrm{mV}$ in $\mathrm{Mg}^{2+}$-free solution (Fig. 4). On one hand, in the presence of NMDA-R blockers, $\mathrm{mf}$ stimulation was unable to elicit a remarkable $\left[\mathrm{Ca}^{2+}\right]_{\mathrm{i}}$ increase (in three cases the response was virtually undetectable), whereas the amplitude of depolarizationinduced $\left[\mathrm{Ca}^{2+}\right]_{\mathrm{i}}$ transients was unaltered [depolarization, $(\Delta \mathrm{F} /$ $\left.F_{0}\right)_{\max }=0.40 \pm 0.07$; mf stimulation, $\left(\Delta F / F_{0}\right)_{\max }=0.07 \pm 0.04 ; n=$ 6; $p<0.001]$. On the other hand, inhibition of mGlu-R1 significantly decreased, but did not abolish, the maximal amplitude of the $\left[\mathrm{Ca}^{2+}\right]_{\mathrm{i}}$ response determined by synaptic stimulation; in addition, in this case, the amplitude of depolarization-induced $\left[\mathrm{Ca}^{2+}\right]_{\mathrm{i}}$ transients was unaltered [depolarization, $\left(\Delta F / F_{0}\right)_{\max }=0.42 \pm 0.06 ; \mathrm{mf}$ stimulation, $\left.\left(\Delta F / F_{0}\right)_{\max }=0.30 \pm 0.09 ; n=5 ; p<0.05\right]$. When the different groups of experiments were compared, inhibition of NMDA-R and mGlu-R1 significantly reduced $\left[\mathrm{Ca}^{2+}\right]_{\mathrm{i}}$ responses by 82.5\% ( $p<0.01$; unpaired $t$ test) and $25.1 \%$ ( $p<0.05$; unpaired $t$ test) compared with controls (Fig. $4 C$ ). These results show that

A

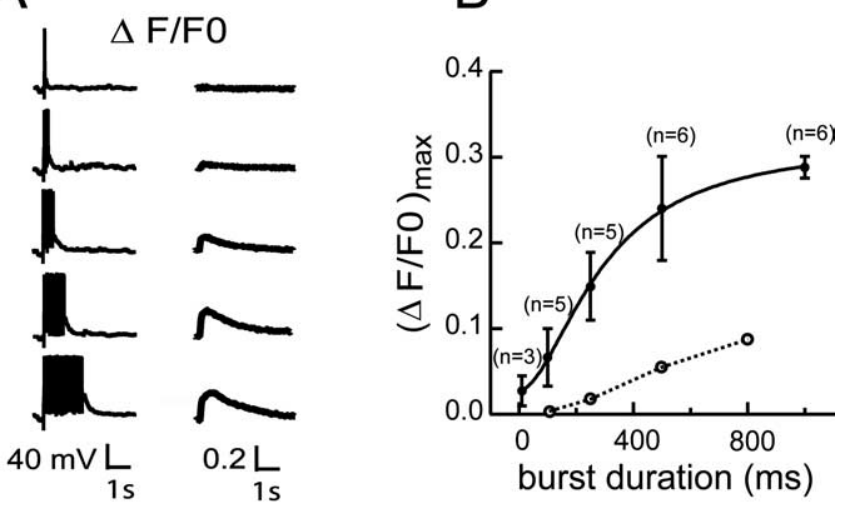

C
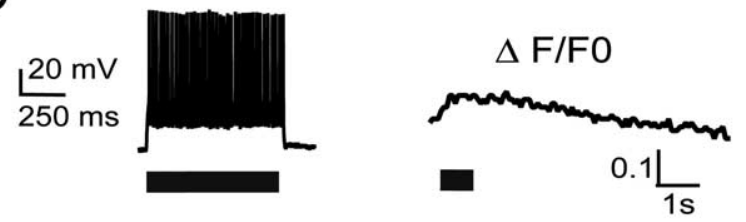

Figure 7. Effect of increasing duration of high-frequency mf stimulation on $\left[\mathrm{Ca}^{2+}\right]_{i}$ transients. A, During a current-clamp recording with $1.2 \mathrm{~mm}$ external $\mathrm{Mg}^{2+}$ starting from a membrane potential of $-65 \mathrm{mV}$, application of 1-100 continuous mf stimuli at $100 \mathrm{~Hz}$ (CS) revealed a progressive increase in the synaptic $\left(\Delta F / F_{0}\right)_{\max }$ on a single $\mathrm{GrC}$, tending to plateau with trains lasting $>500 \mathrm{~ms}$. $\boldsymbol{B}$, The corresponding nonlinear relationship between synaptic $\left(\Delta F / F_{0}\right)_{\max }$ and mf burst duration is shown (filled circles; the number of experiments is indicated). The open circles connected by a dotted line show the $\left(\Delta F / F_{0}\right)_{\text {max }}$ generated by postsynaptic spikes, as shown in C ( $n=4$ for each points; error bars are included within data points). Data are shown as mean \pm SEM. $C_{,}\left[\mathrm{Ca}^{2+}\right]_{\mathrm{i}}$ increase determined by postsynaptic spikes. Repetitive spike discharge was generated by injecting a $25 \mathrm{pA}$ depolarizing pulse in a $\mathrm{GrC}$ (left), and the corresponding $\left[\mathrm{Ca}^{2+}\right]_{\mathrm{i}}$ change was measured (right).

mGlu-Rs are not able to elicit a remarkable $\left[\mathrm{Ca}^{2+}\right]_{\mathrm{i}}$ increase but can potentiate the response triggered by NMDA-R activation.

The role of intracellular stores in $\left[\mathrm{Ca}^{2+}\right]_{\mathrm{i}}$ changes

The contribution of intracellular stores to $\mathrm{Ca}^{2+}$ signaling was assessed by preincubating slices for $30 \mathrm{~min}$ with $500 \mathrm{~nm}$ thapsigargin, an inhibitor of sarcoplasmic/endoplasmic reticulum $\mathrm{Ca}^{2+}$ ATPase (Fig. 5). The $\left[\mathrm{Ca}^{2+}\right]_{\mathrm{i}}$ transient induced by a $200 \mathrm{~ms}$ depolarization from -70 to $0 \mathrm{mV}$ was significantly reduced in amplitude $\left[\left(\Delta F / F_{0}\right)_{\max }=0.22 \pm 0.04 ; n=10\right]$ compared with control recordings without thapsigargin pretreatment $[(\Delta F /$ $\left.F_{0}\right)_{\max }=0.38 \pm 0.04 ; n=18 ; p<0.01$; unpaired $t$ test $]$, and it was curtailed (HW, $1.62 \pm 0.25 \mathrm{~s}$; thapsigargin, $n=10$; HW, $2.59 \pm$ $0.26 \mathrm{~s}$; control, $n=18$; $p<0.05$; unpaired $t$ test). The corresponding area under the curve (AUC) was therefore dramatically reduced [AUC, $481 \pm 110 \mathrm{~ms}$; thapsigargin, $n=9$; AUC, $1141 \pm$ $140 \mathrm{~ms}$; control, $n=18 ; p<0.01$; unpaired $t$ test]. These results indicate a major role of $\mathrm{Ca}^{2+}$ stores in the amplification and protraction of the $\left[\mathrm{Ca}^{2+}\right]_{\mathrm{i}}$ signal in GrC dendrites. This experiment was not repeated during synaptic transmission because intracellular stores can also affect neurotransmitter release during repetitive stimulation (Emptage et al., 2001).

\section{Efficiency of theta-burst patterns in determining} $\left[\mathrm{Ca}^{2+}\right]_{\mathrm{i}}$ changes

In addition to continuous stimulation (Fig. 2C), TBS is a protocol commonly used to induce long-term synaptic plasticity. We in- 
A

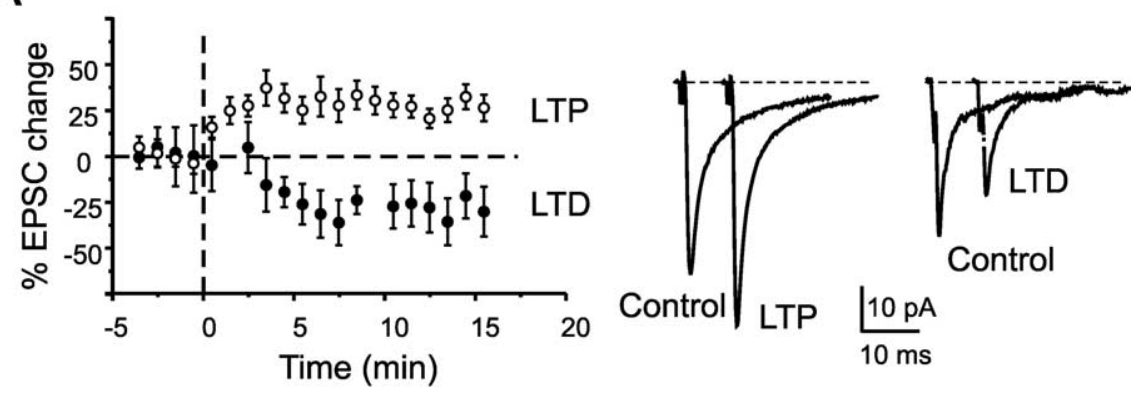

B

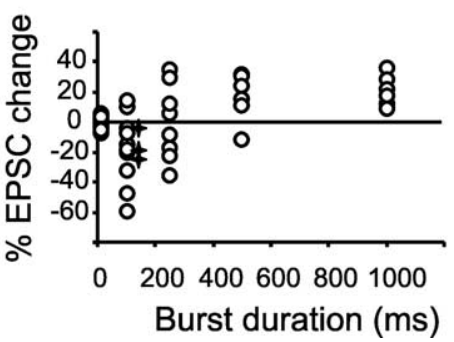

2000). $\left[\mathrm{Ca}^{2+}\right]_{i}$ changes were measured in the dendrite showing the most prominent fluorescence change to exclude nonsynaptically activated dendrites (see below). Application of 1-100 repetitive stimuli at 100 $\mathrm{Hz}$, corresponding to $10-1000 \mathrm{~ms}$ bursts, revealed a progressive $\left[\mathrm{Ca}^{2+}\right]_{\mathrm{i}}$ increase tending to plateau with trains lasting $>500$ ms (Fig. $7 A, B$ ).

Differently from voltage-clamp recordings, synaptic activation could induce membrane depolarization and $\left[\mathrm{Ca}^{2+}\right]_{\mathrm{i}}$ changes mediated by VDCCs also in dendrites that were not activated by glutamate released at the corresponding mossy fiber. The effect of spike discharge on $\left[\mathrm{Ca}^{2+}\right]_{i}$ was investigated in isolation by delivering $800 \mathrm{~ms}$ depolarization from the initial membrane potential of $-70 \mathrm{mV}$ (D'Angelo et al., 1995, 1998). Depolarizing currents elicited repetitive spike discharge at $47.2 \pm 9.3 \mathrm{~Hz}(n=4)$ (Fig. $7 C)$, and, as well as with recordings obtained in voltage clamp, depolarization-evoked $\left[\mathrm{Ca}^{2+}\right]_{\mathrm{i}}$ changes occurred in all visible dendrites (Fig. 7C). The maximum $\left[\mathrm{Ca}^{2+}\right]_{\mathrm{i}}$ increase at the end of $800 \mathrm{~ms}$ stimuli was $\left(\Delta F / F_{0}\right)_{\max }$ $=0.077 \pm 0.03(n=4)$, indicating activation of a fraction of the total VDCC current. The $\left[\mathrm{Ca}^{2+}\right]_{\mathrm{i}}$ change caused by VDCCs was remarkably smaller and could not be confused with that determined by mf bursts of corresponding length (Fig. $7 B$ ).

vestigated $\left[\mathrm{Ca}^{2+}\right]_{\mathrm{i}}$ changes induced by TBS in voltage-clamp recordings mimicking high-frequency pairing used for $\mathrm{mf}-\mathrm{GrC}$ LTP induction in previous works (D'Angelo et al., 1999; Armano et al., 2000; Rossi et al., 2002). GrCs were maintained at $-70 \mathrm{mV}$, and membrane potential was stepped to $-40 \mathrm{mV}$ during $100 \mathrm{~ms}$, $100 \mathrm{~Hz}$ mf bursts repeated every $250 \mathrm{~ms}$ with an extracellular solution containing $1.2 \mathrm{mM} \mathrm{Mg}^{2+}$.

TBS raised $\left[\mathrm{Ca}^{2+}\right]_{\mathrm{i}}$ close to the level attained by $1 \mathrm{~s}, 100 \mathrm{~Hz}$ continuous stimulation ( $n=4)$ (Fig. $6 A)$. Moreover, repeating the TBS twice with a 2 s interval, as is often done in LTP induction experiments, resulted in a protracted $\left[\mathrm{Ca}^{2+}\right]_{\mathrm{i}}$ elevation. The second TBS caused a significant facilitation of the $\left[\mathrm{Ca}^{2+}\right]_{\mathrm{i}}$ signal $\left[\left(\Delta F / F_{0}\right)_{\max 2} /\left(\Delta F / F_{0}\right)_{\max 1}=1.49 \pm 0.12 ; n=4 ; p<0.05\right]$. No comparable facilitation was observed with $200 \mathrm{~ms}$ depolarizing pulses from -70 to $0 \mathrm{mV}\left[\left(\Delta F / F_{0}\right)_{\max 2} /\left(\Delta F / F_{0}\right)_{\max 1}=1.13 \pm\right.$ $0.04 ; n=4]$, presumably reflecting faster decay and weaker temporal summation of $\mathrm{Ca}^{2+}$ transients. $\left[\mathrm{Ca}^{2+}\right]_{i}$ changes caused by continuous stimulation and TBS are compared in Figure $6 B$, showing that TBS can efficiently elevate $\left[\mathrm{Ca}^{2+}\right]_{\mathrm{i}}$.

\section{The effect of burst duration on $\left[\mathrm{Ca}^{2+}\right]_{i}$ changes}

Mfs are known to discharge in repetitive bursts of variable length and frequency (Kase et al., 1980; Szwed et al., 2003; Chadderton et al., 2004). To investigate the impact of $\mathrm{mf}$ bursts on $\left[\mathrm{Ca}^{2+}\right]_{\mathrm{i}}$ changes, we maintained GrCs in current clamp, mimicking conditions used during the induction of synaptic plasticity with an extracellular solution containing $1.2 \mathrm{~mm} \mathrm{Mg}^{2+}$. The initial membrane potential was set between -70 and $-55 \mathrm{mV}$ with constant current injection, so that $\mathrm{mf}$ stimulation bursts elicited repetitive action potential discharge $(40.8 \pm 4.4 \mathrm{~Hz} ; n=25)$ (Armano et al.,
These results, in conjunction with those shown in Figures 2 and 6, show that short bursts such as those generated by single tactile stimuli (Szwed et al., 2003; Chadderton et al., 2004) determine a sizeable dendritic $\left[\mathrm{Ca}^{2+}\right]_{\mathrm{i}}$ increase, which is remarkably amplified by burst repetition or prolongation. Moreover, GrC firing contributes to elevating $\left[\mathrm{Ca}^{2+}\right]_{\mathrm{i}}$ through VDCCs also in the dendrites that are not synaptically stimulated.

\section{The effect of burst duration on synaptic plasticity} has been reported at the $\mathrm{mf}-\mathrm{GrC}$ relay after high-frequency repetitive mf stimulation (D'Angelo et al., 1999; Armano et al., 2000; Maffei et al., 2002, 2003; Sola et al., 2004). However, no systematic investigation of the conditions leading to LTP or to the potential generation of LTD were performed. Here, we report the effect of stimulation paradigms identical to those used for investigating $\left[\mathrm{Ca}^{2+}\right]_{\mathrm{i}}$ dynamics in Figure 7 (mf bursts elicited repetitive action potential discharge at $36.9 \pm 4.4 \mathrm{~Hz} ; n=23$ ), with the aim of establishing a correlation among $\mathrm{mf}$ activity, synaptic plasticity, and the biochemical mechanisms involved.

At low frequency $(0.1 \mathrm{~Hz})$, EPSCs did not show apparent changes in their amplitude along recordings. Application of a single $100 \mathrm{~Hz}$ burst of duration ranging from 100 to $1000 \mathrm{~ms}$ in current clamp revealed a characteristic plasticity profile. Figure $8 \mathrm{~A}$ shows the time course of LTD induced by a $100 \mathrm{~ms}$ burst and of LTP induced by a $1000 \mathrm{~ms}$ burst. The EPSC changes persisted until the end of the recordings (up to $60 \mathrm{~min}$ in three LTD and four LTP recordings; data not shown). Figure $8 B$ shows the scatter of EPSC changes measured near steady state for bursts of different duration. Burst duration determined the probability of
NMDA-R-dependent $\mathrm{Ca}^{2+}$-dependent long-term potentiation 
A

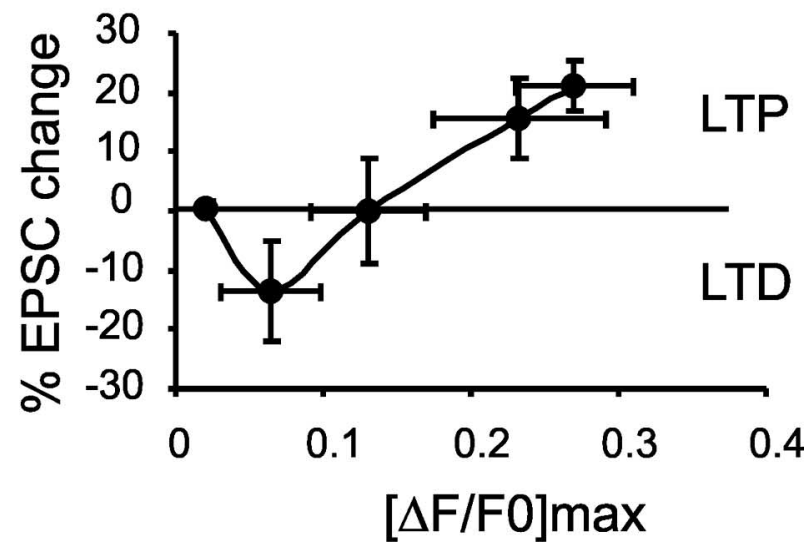

B

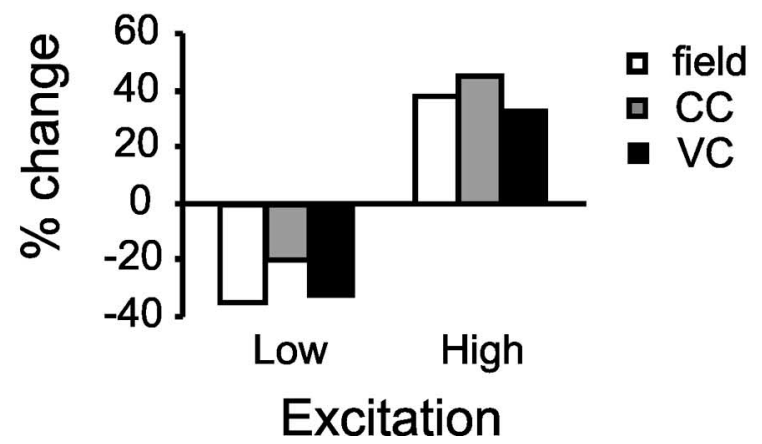

Figure 9. Plasticity/[Ca $\left.{ }^{2+}\right]_{\mathrm{i}}$ relationship. $\boldsymbol{A}$, The plot reports plasticity versus $\left[\mathrm{Ca}^{2+}\right]_{\mathrm{i}}$ taken at the same burst duration. The BCM-like shape observed in Figure $8 C$ is maintained, although saturation is less evident. Data are reported as mean \pm SEM. $\boldsymbol{B}$, Bidirectional synaptic changes observed in different recording conditions: inhibition absent or present (field recordings) (Maffei et al., 2002), membrane potential at either -70 or $-45 \mathrm{mV}$ [current clamp (CC)] (Armano et al., 2000), high or low $\mathrm{Ca}^{2+}$ buffering [voltage clamp (VC)] (D'Angelo et al., 1999). Error bars represent SEM.

inducing LTP rather than LTD, with LTD being much more probable at $100 \mathrm{~ms}$ and LTP at $1000 \mathrm{~ms}$. LTD and LTP were equally probable at $250 \mathrm{~ms}$. On average, $100 \mathrm{~ms}$ bursts ( 10 pulses) caused LTD, $250 \mathrm{~ms}$ bursts (25 pulses) did not cause any net plasticity, and 500-1000 ms bursts (50-100 pulses) determined LTP (Fig. 8C).

The relationship between synaptic plasticity and $\left[\mathrm{Ca}^{2+}\right]_{\mathrm{i}}$ is shown in Figure 9A. The plot shows a BCM-like shape, with no changes at very low $\left[\mathrm{Ca}^{2+}\right]_{\mathrm{i}}$, LTD for moderate $\left[\mathrm{Ca}^{2+}\right]_{\mathrm{i}}$, and, after a neutral point, LTP at relatively high $\left[\mathrm{Ca}^{2+}\right]_{\mathrm{i}}$. Figure $9 B$ summarizes previous observations, which, a posteriori, would suggest the existence of bidirectional plasticity in field (Maffei et al., 2002), voltage-clamp (D'Angelo et al., 1999), or currentclamp recordings (Armano et al., 2000).

\section{Discussion}

In this paper, we provide the first analysis of $\left[\mathrm{Ca}^{2+}\right]_{\mathrm{i}}$ regulation in GrCs during synaptic transmission. $\left[\mathrm{Ca}^{2+}\right]_{\mathrm{i}}$ dynamics measured in the dendrites were determined by multiple mechanisms involving NMDA-Rs, mGlu-Rs, VDCCs, and intracellular $\mathrm{Ca}^{2+}$ stores. The major finding is that burst patterns related to native mf discharge determine the balance between LTP and LTD through postsynaptic $\left[\mathrm{Ca}^{2+}\right]_{\mathrm{i}}$ regulation.

GrCs investigated using confocal microscopy showed a typical morphology with a small spherical soma emitting an average of four short dendrites terminating with two to four digitiform endings. This morphology corresponded to that reported using Golgi staining and electron microscopy (Eccles et al., 1967; Palay and Chan-Palay, 1974; Jakab and Hamori, 1988). Fluorescent $\mathrm{Ca}^{2+}$ imaging showed that $\left[\mathrm{Ca}^{2+}\right]_{\mathrm{i}}$ increase determined by membrane depolarization or $\mathrm{mf}$ stimulation was confined to dendrites. Moreover, synaptically driven $\left[\mathrm{Ca}^{2+}\right]_{\mathrm{i}}$ increase could be observed in a fraction of the dendrites responding to membrane depolarization, implying regional segregation of $\mathrm{Ca}^{2+}$ signaling. Local $\mathrm{Ca}^{2+}$ control by synaptic stimuli is commonly observed in spines and smooth dendrites of pyramidal neurons (Svoboda et al., 1996; Sabatini et al., 2001, 2002; Augustine et al., 2003; Goldberg et al., 2003). $\mathrm{Ca}^{2+}$ signals observed in the soma of GrCs in culture (Irving et al., 1992a,b; del Rio et al., 1999; Masgrau et al., 2001) may reflect different recording or cellular conditions, as well as the massive, protracted nonlocalized stimulation caused by bath perfusion of high- $\mathrm{K}^{+}$solutions or glutamate receptor agonists.

The response to depolarization and $\mathrm{mf}$ stimulation revealed the action of the three main $\left[\mathrm{Ca}^{2+}\right]_{\mathrm{i}}$ regulatory mechanisms of the GrC membrane. Membrane depolarization activated highthreshold VDCCs (Rossi et al., 1994). Glutamate released by $\mathrm{mf}$ discharge activated NMDA-Rs and mGlu-Rs (D'Angelo et al., 1993, 1995; Rossi et al., 1996). NMDA-Rs are permeable to $\mathrm{Ca}^{2+}$, and mGlu-Rs probably act through the $\mathrm{IP}_{3}$ pathway, which is effectively stimulated by glutamate in GrCs (del Rio et al., 1999; Masgrau et al., 2001; Monti et al., 2002). During repetitive synaptic transmission, the main contribution to $\left[\mathrm{Ca}^{2+}\right]_{i}$ was given by NMDA-R, whereas mGlu-R1 could play an amplifying role (Finch et al., 1991; Irving et al., 1992b), explaining the need for NMDA-R and mGlu-R coactivation in $\mathrm{mf}-\mathrm{GrC}$ LTP induction (Rossi et al., 1996; D’Angelo et al., 1999; Maffei et al., 2002). Ca ${ }^{2+}$ entry through VDCCs, by signaling membrane depolarization and repetitive spike discharge (Armano et al., 2000), could also favor $\mathrm{mf}-\mathrm{GrC}$ LTP. $\mathrm{Ca}^{2+}$ signals were remarkably amplified and protracted by $\mathrm{Ca}^{2+}$-induced $\mathrm{Ca}^{2+}$ release (CICR), as indicated by the effect of thapsigargin (and also observed in $\mathrm{GrC}$ culture) (Irving et al., 1992a,b; Simpson et al., 1996), suggesting that CICR plays a critical role in the induction of long-term plasticity (Nishiyama et al., 2000) at the $\mathrm{mf}-\mathrm{GrC}$ synapse. It should be noted that GrC $\left[\mathrm{Ca}^{2+}\right]_{\mathrm{i}}$ regulatory mechanisms could be differently engaged, depending on $\mathrm{mf}-\mathrm{GrC}$ operating conditions. $\mathrm{Ca}^{2+}$ entry through NMDA channels can be regulated by factors controlling membrane depolarization, especially Golgi cell inhibition and $\mathrm{mf}$ number, discharge frequency, and correlation. $\mathrm{Ca}^{2+}$ release through the $\mathrm{IP}_{3}$ pathway is solely regulated by mGlu receptor activation and may therefore be sensitive to burst duration and frequency. Finally, $\mathrm{Ca}^{2+}$ entry through VDCCs, which activate during the action potential upstroke (D'Angelo et al., 1997, 1998), signals GrC discharge. Thus, as at other central synapses (Jaffe and Brown, 1994; Yang et al., 1999; Nishiyama et al., 2000; Cho et al., 2001; Cormier et al., 2001), GrC dendrites are endowed with $\mathrm{Ca}^{2+}$ regulation systems appropriate for detecting the coincidence of presynaptic and postsynaptic activity and for controlling bidirectional plasticity. It should be noted that $\left[\mathrm{Ca}^{2+}\right]_{\mathrm{i}}$ signaling has also been investigated in the presynaptic terminals that parallel fibers (the granule cell axons) form in the molecular layer with Purkinje cells [see study by Dittman et al. (2003) and references therein]. In parallel fiber terminals, $\mathrm{Ca}^{2+}$ 
influx is regulated by VDCCs and (probably) presynaptic NMDA receptors controlling short-term release dynamics and parallel fiber-Purkinje cell LTD (Casado et al., 2002).

Mf activity caused a $\left[\mathrm{Ca}^{2+}\right]_{i}$ increase raising sharply with burst duration, and long-term synaptic plasticity was clearly correlated with the duration of stimulus trains through $\left[\mathrm{Ca}^{2+}\right]_{\mathrm{i}}$. The plasticity/ $\left[\mathrm{Ca}^{2+}\right]_{\mathrm{i}}$ curve resembled the BCM learning rule (Bienenstock et al., 1982) (Fig. 9A), with no changes with isolated stimuli, LTD with a single short burst $(100 \mathrm{~ms})$, and, after a neutral point, LTP with a longer burst $(>500 \mathrm{~ms})$. In the region extending from 100 to $500 \mathrm{~ms}$, the plasticity/[ $\left.\mathrm{Ca}^{2+}\right]_{\mathrm{i}}$ curve approximated a simple covariance rule (Stanton and Sejnowski, 1989). Repetition of 100 ms bursts in TBS sequences also yielded nearly maximal $\left[\mathrm{Ca}^{2+}\right]_{\mathrm{i}}$ and caused saturating LTP (Armano et al., 2000; Rossi et al., 2002). This result suggests that the doublethreshold hypothesis developed for hippocampal synapses (Mulkey and Malenka, 1992; Artola and Singer, 1993), in which moderate $\mathrm{Ca}^{2+}$ levels activate phosphatases leading to LTD, whereas high $\mathrm{Ca}^{2+}$ levels activate kinases leading to LTP (Lisman, 1989, 2001, 2003; Kevin and Sejnowski, 2002; Siöström and Nelson, 2002), could also be appropriate for the mf- GrC synapse of cerebellum. Interestingly, bidirectional plasticity was also revealed at other cerebellar synapses (for review, see Hansel et al., 2001). For instance, in parallel fiber-Purkinje cell LTD, large $\left[\mathrm{Ca}^{2+}\right]_{\mathrm{i}}$ signals are generated by $\mathrm{P}$-type channel activation during complex spikes caused by the climbing fiber and are reinforced by mGluR1 signaling through $\mathrm{IP}_{3}$ receptors and nitric oxide (NO) release caused by parallel fibers. The absence of climbing fiber activity and weak $\left[\mathrm{Ca}^{2+}\right]_{\mathrm{i}}$ signals cause LTP, demonstrating heterosynaptic bidirectional plasticity implementing a reverse BCM rule (Coesmans et al., 2004). In addition to this, a presynaptic cAMP-dependent and a postsynaptic NO-dependent form of parallel fiber-Purkinje cell LTP have been observed (Lev-Ram et al., 2002). In deep cerebellar nuclear cells, bidirectional plasticity depends on the intensity of T-type channel activation during the rebound depolarization after Purkinje cell inhibition (Aizenman et al., 1998).

Mf bursts typically last 50-150 ms (Chadderton et al., 2004) and can recur in theta patterns during active sensation, e.g., during whisking (Szwed et al., 2003). It is therefore expected that sporadic stimuli either are ineffective or cause LTD, whereas those related to purposeful active sensation determine LTP. Mfs are also capable of relaying frequency-modulated signals, e.g., during eye movements (Kase et al., 1980). The sensitivity of $\left[\mathrm{Ca}^{2+}\right]_{\mathrm{i}}$ changes and synaptic plasticity to different input frequencies remains to be investigated. The present result also allows the interpretation of previously unexplained observations (Fig. 9B), in which persistent bidirectional changes in synaptic strength followed manipulations of postsynaptic depolarization (Armano et al., 2000), Golgi cell inhibition (Maffei et al., 2002), or intracellular $\mathrm{Ca}^{2+}$ buffering (D’Angelo et al., 1999).

In conclusion, $\mathrm{mf}$ input bursts can be efficiently translated into $\mathrm{GrC}\left[\mathrm{Ca}^{2+}\right]_{\mathrm{i}}$ changes allowing synapse-specific bidirectional long-term synaptic plasticity. Although $\mathrm{Ca}^{2+}$ signals determined by glutamate receptor activation are confined to individual dendrites, membrane potential is homogeneously distributed because of the high electrotonic compactness of GrCs (Silver et al., 1992; D'Angelo et al., 1993, 1995). Thus, whether an mf-GrC synapse develops LTP or LTD will depend on local glutamate receptor activation and global membrane potential control resembling input selectivity and cooperativity of Hebbian longterm synaptic plasticity in the hippocampus (Hebb, 1949; Bliss and Collingridge, 1993). The depolarization-driven $\mathrm{Ca}^{2+}$ raise observed in synaptically inactive dendrites, in addition to modulating ionic channels (D’Angelo et al., 1998, 2001), might promote heterosynaptic forms of plasticity (Lei et al., 2003). Bidirectional long-term synaptic plasticity could have a remarkable impact on the way the cerebellum granular layer processes incoming input patterns. In theoretical models, bidirectional $\mathrm{mf}-$ GrC plasticity indeed proved critical for optimizing information transfer through the mf pathway (Schweighofer et al., 2001; Philipona et al., 2004), regulating pattern recognition and sensorimotor control.

\section{References}

Aizenman CD, Manis PB, Linden DJ (1998) Polarity of long-term synaptic gain change is related to postsynaptic spike firing at a cerebellar inhibitory synapse. Neuron 21:827-835.

Armano S, Rossi P, Taglietti V, D’Angelo E (2000) Long-term potentiation of intrinsic excitability at the mossy fiber-granule cell synapse of rat cerebellum. J Neurosci 20:5208-5216.

Artola A, Singer W (1993) Long-term depression of excitatory synaptic transmission and its relationship to long-term potentiation. Trends Neurosci 16:480-487.

Augustine GJ, Santamaria F, Tanaka K (2003) Local calcium signaling in neurons. Neuron 40:331-346.

Bienenstock EL, Cooper LN, Munro PW (1982) Theory for the development of neuron selectivity: orientation specificity and binocular interaction in visual cortex. J Neurosci 2:32-48.

Bliss TV, Collingridge GL (1993) A synaptic model of memory: long-term potentiation in the hippocampus. Nature 361:31-39.

Bliss TV, Collingridge GL, Morris RG (2003) Long-term potentiation and structure of the issue. Philos Trans R Soc Lond B Biol Sci 358:607-611.

Casado M, Isope P, Ascher P (2002) Involvement of presynaptic N-methylD-aspartate receptors in cerebellar long-term depression. Neuron 33:123-130.

Cathala L, Brickley S, Cull-Candy S, Farrant M (2003) Maturation of EPSCs and intrinsic membrane properties enhances precision at a cerebellar synapse. J Neurosci 23:6074-6085.

Chadderton P, Margrie TW, Hausser M (2004) Integration of quanta in cerebellar granule cells during sensory processing. Nature 428:856-860.

Cho K, Aggleton JP, Brown MW, Bashir ZI (2001) An experimental test of the role of postsynaptic calcium levels in determining synaptic strength using perirhinal cortex of rat. J Physiol (Lond) 532:459-466.

Coesmans M, Weber JT, De Zeeuw CI, Hansel C (2004) Bidirectional parallel fiber plasticity in the cerebellum under climbing fiber control. Neuron 44:691-700.

Cormier RJ, Greenwood AC, Connor JA (2001) Bidirectional synaptic plasticity correlated with the magnitude of dendritic calcium transients above a threshold. J Neurophysiol 85:399-406.

D’Angelo E, Rossi P, Taglietti V (1993) Different proportions of N-methyl$\mathrm{D}$-aspartate and non- $N$-methyl-D-aspartate receptor currents at the mossy fibre-granule cell synapse of developing rat cerebellum. Neuroscience 53:121-130.

D’Angelo E, Rossi P, De Filippi G, Magistretti J, Taglietti V (1994) The relationship between synaptogenesis and expression of voltagedependent currents in cerebellar granule cells in situ. J Physiol (Paris) 88:197-207.

D’Angelo E, De Filippi G, Rossi P, Taglietti V (1995) Synaptic excitation of individual rat cerebellar granule cells in situ: evidence for the role of NMDA receptors. J Physiol (Lond) 484:397-413.

D’Angelo E, De Filippi G, Rossi P, Taglietti V (1997) Synaptic activation of $\mathrm{Ca}^{2+}$ action potentials in immature rat cerebellar granule cells in situ. J Neurophysiol 78:1631-1642.

D’Angelo E, De Filippi G, Rossi P, Taglietti V (1998) Ionic mechanism of electroresponsiveness in cerebellar granule cells implicates the action of a persistent sodium current. J Neurophysiol 80:493-503.

D’Angelo E, Rossi P, Armano S, Taglietti V (1999) Evidence for NMDA and $\mathrm{mGlu}$ receptor-dependent long-term potentiation of mossy fibre-granule cell transmission in rat cerebellum. J Neurophysiol 81:277-287.

D’Angelo E, Nieus T, Maffei A, Armano S, Rossi P, Taglietti V, Fontana A, Naldi G (2001) Theta-frequency bursting and resonance in cerebellar granular cells: experimental evidence and modeling of a slow K-dependent mechanism. J Neurosci 21:759-770. 
del Rio E, McLaughlin M, Downes CP, Nicholls DG (1999) Differential coupling of G-protein-linked receptors to $\mathrm{Ca}^{2+}$ mobilization through inositol $(1,4,5)$ trisphosphate or ryanodine receptors in cerebellar granule cells in primary culture. Eur J Neurosci 11:3015-3022.

DeMaria CD, Soong TW, Alseikhan BA, Alvania RS, Yue DT (2001) Calmodulin bifurcates the local $\mathrm{Ca}^{2+}$ signal that modulates $\mathrm{P} / \mathrm{Q}$ type $\mathrm{Ca}^{2+}$ channels. Nature 411:484-489.

Dittman JS, Kreitzer AC, Regehr WG (2000) Interplay between facilitation, depression, and residual calcium at three presynaptic terminals. J Neurosci 20:1374-1385.

Eccles JC, Ito M, Szentagothai J (1967) The cerebellum as a neuronal machine. Berlin: Springer.

Emptage NJ, Reid CA, Fine A (2001) Calcium stores in hippocampal synaptic boutons mediate short-term plasticity, store-operated $\mathrm{Ca}^{2+}$ entry, and spontaneous transmitter release. Neuron 29:197-208.

Finch EA, Turner TJ, Goldin SM (1991) Calcium as a coagonist of inositol 1,4,5-trisphosphate-induced calcium release. Science 252:443-446.

Forti L, Pouzat C, Llano I (2000) Action potential-evoked $\mathrm{Ca}^{2+}$ signals and calcium channels in axons of developing rat cerebellar interneurones. J Physiol (Lond) 527:33-48.

Gall D, Roussel C, Susa I, D’Angelo E, Rossi P, Bearzatto B, Galas M-C, Blum D, Schurmans S, Schiffmann S (2003) Altered neuronal excitability in cerebellar granule cells of mice lacking calretinin. J Neurosci 23:93209327.

Goldberg JH, Tamas G, Aronov D, Yuste R (2003) Calcium microdomains in aspiny dendrites. Neuron 40:807-821.

Hansel C, Artola A, Singer W (1997) Relation between dendritic $\mathrm{Ca}^{2+}$ levels and the polarity of synaptic long-term modifications in rat visual cortex neurons. Eur J Neurosci 9:2309-2322.

Hansel C, Linden DJ, D’Angelo E (2001) Beyond parallel fiber LTD: the diversity of synaptic and non-synaptic plasticity in the cerebellum. Nat Neurosci 4:467-475.

Hebb DO (1949) The organization of behavior. New York: Wiley.

Irving AJ, Collingridge GL, Schofield JG (1992a) L-glutamate and acetylcholine mobilise $\mathrm{Ca}^{2+}$ from the same intracellular pool in cerebellar granule cells using transduction mechanisms with different $\mathrm{Ca}^{2+}$ sensitivities. Cell Calcium 13:293-301.

Irving AJ, Collingridge GL, Schofield JG (1992b) Interactions between $\mathrm{Ca}^{2+}$ mobilizing mechanisms in cultured rat cerebellar granule cells. J Physiol (Lond) 456:667-680.

Jaffe DB, Brown TH (1994) Metabotropic glutamate receptor activation induces calcium waves within hippocampal dendrites. J Neurophysiol 72:471-474.

Jakab RL, Hamori J (1988) Quantitative morphology and synaptology of cerebellar glomeruli in the rat. Anat Embryol (Berl) 179:81-88.

Kase M, Miller DC, Noda H (1980) Discharges of Purkinje cells and mossy fibres in the cerebellar vermis of the monkey during saccadic eye movements and fixation. J Physiol (Lond) 300:539-555.

Kevin MF, Sejnowski TJ (2002) Complexity of calcium signaling in synaptic spines. BioEssays 24:1130-1144.

Krahe R, Gabbiani F (2004) Burst firing in sensory systems. Nat Neurosci 5:13-23.

Lei S, Pelkey KA, Topolnik L, Congar P, Lacaille JC, McBain CJ (2003) Depolarization-induced long-term depression at hippocampal mossy fiber-CA3 pyramidal neuron synapses. J Neurosci 23:9786-9795.

Lev-Ram V, Wong ST, Storm DR, Tsien RY (2002) A new form of cerebellar long-term potentiation is postsynaptic and depends on nitric oxide but not cAMP. Proc Natl Acad Sci USA 99:8389-8393.

Lisman JE (1989) A mechanism for the Hebb and the anti-Hebb processes underlying learning and memory. Proc Natl Acad Sci USA 86:9574-9578.

Lisman JE (1997) Bursts as a unit of neuronal information: making unreliable synapses reliable. Trends Neurosci 20:38-43.

Lisman JE (2001) Three $\mathrm{Ca}^{2+}$ levels affect plasticity differently: the LTP zone, the LTD zone and no man's land. J Physiol (Lond) 532:285.

Lisman JE (2003) Long-term potentiation: outstanding questions and attempted synthesis. Philos Trans R Soc Lond B Biol Sci 358:829-842.
Maffei A, Prestori F, Rossi P, Taglietti V, D’Angelo E (2002) Presynaptic current changes at the mossy fiber-granule cell synapse of cerebellum during LTP. J Neurophysiol 88:627-638.

Maffei A, Prestori F, Shibuki K, Rossi P, Taglietti V, D’Angelo E (2003) NO enhances presynaptic currents during cerebellar mossy fiber-granule cell LTP. J Neurophysiol 90:2478-2483.

Malenka RC, Nicoll RA (1999) Long-term potentiation-a decade of progress? Science 285:1870-1874.

Masgrau R, Servitja JM, Young KW, Pardo R, Sarri E, Nahorski SR, Picatoste F (2001) Characterization of the metabotropic glutamate receptors mediating phospholipase $\mathrm{C}$ activation and calcium release in cerebellar granule cells: calcium-dependence of the phospholipase C response. Eur J Neurosci 13:248-256.

Monti B, Marri L, Contestabile A (2002) NMDA receptor-dependent CREB activation in survival of cerebellar granule cells during in vivo and in vitro development. Eur J Neurosci 16:1490-1498.

Mulkey RM, Malenka RC (1992) Mechanisms underlying induction of homosynaptic long-term depression in area CA1 of hippocampus. Neuron 9:967-975.

Neveu D, Zucker RS (1996) Postsynaptic levels of $\left[\mathrm{Ca}^{2+}\right]_{\mathrm{i}}$ needed to trigger LTD and LTP. Neuron 1996:16:619-629.

Nishiyama M, Hong K, Mikoshiba K, Poo MM, Kato K (2000) $\mathrm{Ca}^{2+}$ stores regulate the polarity and input specificity of synaptic modification. Nature 408:584-588.

Palay SL, Chan-Palay V (1974) Cerebellar cortex, pp 63-99, 142-179. Berlin: Springer.

Philipona D, Coenen OJ-M (2004) Model of granular layer encoding of the cerebellum. Neurocomputing 58-60:575-580.

Rossi P, D’Angelo E, Magistretti J, Toselli M, Taglietti V (1994) Agedependent expression of high-voltage activated calcium currents during cerebellar granule cell development in situ. Pflügers Arch 429:107-116.

Rossi P, D’Angelo E, Taglietti V (1996) Differential long-lasting potentiation of the NMDA and non-NMDA synaptic currents induced by metabotropic and NMDA receptor coactivation in cerebellar granule cells. Eur J Neurosci 8:1182-1189.

Rossi P, Sola E, Taglietti V, Borchardt T, Steigerwald F, Utvik K, Ottersen OP, Kohr G, D'Angelo E (2002) Cerebellar synaptic excitation and plasticity require proper NMDA receptor positioning and density in granule cells. J Neurosci 22:9687-9697.

Sabatini BL, Maravall M, Svoboda K (2001) $\mathrm{Ca}^{2+}$ signaling in dendritic spines. Curr Opin Neurobiol 11:349-356.

Sabatini BL, Oertner TG, Svoboda K (2002) The life cycle of $\mathrm{Ca}^{2+}$ ions in dendritic spines. Neuron 33:439-452.

Schweighofer N, Doya K, Lay F (2001) Unsupervised learning of granule cell sparse codes enhances cerebellar adaptive control. Neuroscience 103:35-50.

Silver RA, Traynelis SF, Cull-Candy SG (1992) Rapid time-course miniature and evoked excitatory currents at cerebellar synapses in situ. Nature 355:163-166.

Simpson PB, Nahorski SR, Challiss RAJ (1996) Agonist-evoked $\mathrm{Ca}^{2+}$ mobilization from stores expressing inositol 1,4,5-trisphosphate receptors and ryanodine receptors in cerebellar granule cells. J Neurochem 67:364-373.

Siöström PJ, Nelson SB (2002) Spike timing, calcium signals and synaptic plasticity. Curr Opin Neurobiol 12:305-314.

Sola E, Prestori F, Rossi P, Taglietti V, D’Angelo E (2004) Increased neurotransmitter release during long-term potentiation at mossy fibre-granule cell synapses in rat cerebellum. J Physiol (Lond) 557:843-861.

Stanton PK, Sejnowski TJ (1989) Associative long-term depression in the hippocampus induced by hebbian covariance. Nature 339:215-218.

Svoboda K, Tank DW, Denk W (1996) Direct measurement of coupling between dendritic spines and shafts. Science 272:716-719.

Szwed M, Bagdasarian K, Ahissar E (2003) Encoding of vibrissal active touch. Neuron 40:621-630.

Yang S-N, Tang Y-G, Zucker RS (1999) Selective induction of LTP and LTD by postsynaptic $\left[\mathrm{Ca}^{2+}\right]_{\mathrm{i}}$ elevation. J Neurophysiol 81:781-787. 